\title{
Land-Based Pollution in the Arctic Ocean: Canadian Actions in a Regional and Global Context
}

\author{
ENVIRONMENT CANADA, ${ }^{1}$ FISHERIES AND OCEANS CANADA ${ }^{2}$ \\ and INDIAN AND NORTHERN AFFAIRS CANADA ${ }^{3}$
}

(Received 26 June 2007; accepted in revised form 2 April 2008)

\begin{abstract}
The occurrence of high concentrations of anthropogenic contaminants in the Arctic environment has been a concern for many years. The present overview of the current threats of pollutants from atmospheric, oceanic, river, and local pathways uses results from recent national, pan-Arctic, and international reports to emphasize the need to address issues arising from climate change, particularly the effect of changing weather patterns on contaminant transportation via both waterways and the atmosphere. Regional and international actions over the past two decades attempting to manage pollutants in the Arctic environment from landbased sources have produced recommendations that focus primarily on increasing cooperation in research and monitoring activities, not only among the Arctic governments themselves, but also including the interests and resources of non-polar countries. Our Canadian perspective on the domestic and circumpolar context of the issue, with regard to mechanisms exerting immediate control on the spread of contaminants, describes national programs and policies that are important to the Canadian North and to the Arctic community as a whole. All levels of Canadian government, as well as foreign governments, have joined in working towards safeguarding the Arctic and other marine environments. Prioritization of concerns is an important approach to tackling the numerous current issues related to the spread of contaminants in the Arctic environment. The government needs to give increased priority to the North, and that action needs to be taken in partnership with local communities and pursued at the regional, national, and international levels.
\end{abstract}

Key words: Arctic, contaminants, land-based pollution, coastal zone, Arctic policies, Arctic Council

RÉSUMÉ. La présence de fortes concentrations de contaminants anthropogéniques dans l'environnement arctique est une source d'inquiétude depuis des années. Le présent aperçu des menaces actuelles découlant des polluants provenant de l'atmosphère, des océans, des fleuves et rivières ainsi que de la région s' appuie sur les résultats de récents rapports d'envergure nationale, panarctique et internationale pour faire ressortir la nécessité de résoudre les enjeux résultant du changement climatique, plus particulièrement l'effet de la situation météorologique changeante sur le transport des contaminants, tant par les cours d'eau que par l'atmosphère. Ces vingt dernières années, les mesures prises à l'échelle régionale et internationale pour tenter de gérer les polluants de sources terrestres dans l'environnement arctique ont donné lieu à des recommandations qui visent principalement une coopération accrue sur le plan des activités de recherche et de surveillance, non seulement au sein des gouvernements arctiques mêmes, mais aussi en faisant appel aux intérêts et aux ressources des pays non polaires. Notre perspective canadienne sur le contexte intérieur et circumpolaire à propos de cette question, en ce qui a trait aux mécanismes qui exercent un contrôle immédiat sur la propagation des contaminants, décrit des politiques et des programmes nationaux qui sont importants aux yeux des collectivités du Nord canadien et de l'Arctique dans l'ensemble. Tous les échelons de gouvernement canadien, de même que de gouvernements étrangers, travaillent de concert pour protéger l'environnement de l'Arctique et d'autres environnements marins. La priorisation des préoccupations constitue une manière importante de s'attaquer aux nombreux enjeux actuels relatifs à la propagation des contaminants dans l'environnement arctique. Le gouvernement doit accorder une priorité accrue au Nord, et cela doit se faire en collaboration avec les collectivités de la région, en plus de s'étendre aux échelons régionaux, nationaux et internationaux.

Mots clés : Arctique, contaminants, pollution de source terrestre, zone côtière, politiques de l'Arctique, Arctic Council

Traduit pour la revue Arctic par Nicole Giguère.

\footnotetext{
${ }^{1}$ National Programme of Action for the Protection of Marine Environments from Land-based Activities (NPA), NPA Secretariat, Environment Canada, 351 St. Joseph Boulevard, 8th floor, Gatineau, Quebec K1A 0H3, Canada; sarah.kennedy@ec.gc.ca

${ }^{2}$ Oceans Directorate, Fisheries and Oceans Canada, 200 Kent Street, Ottawa, Ontario K1A 0E6, Canada; booklessc@ dfo-mpo.gc.ca

${ }^{3}$ Land and Water Management Directorate, Indian and Northern Affairs Canada, 15/25 Wellington Street, Ottawa, Ontario K1A 0H4, Canada; copleym@ainc-inac.gc.ca

(c) The Arctic Institute of North America
} 


\section{INTRODUCTION}

This paper demonstrates the complexity and breadth of the issues of Arctic contamination, reviews the progress towards the management of risks and impacts associated with these contaminants, and comments on the proposed path towards rectification and appropriate management of these concerns. Much of the information has been extracted from two assessments conducted by the Arctic Monitoring and Assessment Programme (AMAP) Working Group (www.amap.no) of the Arctic Council, namely the Arctic Pollution Issues: A State of the Arctic Environment Report (1997), and Arctic Pollution 2002 (2002).

The ocean facing Canada's northern coast is less familiar than the Atlantic to the east and the Pacific to the west, but it is by no means of minor importance. The Arctic Ocean covers some nine million square kilometres and has eight major seas: the Beaufort, Chukchi, East Siberian, Laptev, Kara, Barents, Norwegian, and Greenland seas (Fig. 1). Arctic seas are rich in living marine resources, and some have extensive hydrocarbon resources. The sustainable development and use of coastal and offshore natural resources is an important concern for all Arctic countries. For example, $18 \%$ of the United States domestic oil production is extracted from the Alaska North Slope (Alaska Department of Natural Resources, 2003), and the Bering and Barents seas each provide about $10 \%$ of the world supply of fisheries products.

Four major rivers drain large regions of the Russian Federation (Yenisei, Ob, and Lena rivers) and of Canada (Mackenzie River), providing a total of $3300 \mathrm{~km}^{3}$ per year of freshwater to the Arctic Ocean. These rivers flow onto the world's largest continental shelf, and their combined discharge is nearly $10 \%$ of the river discharge to the world oceans.

The Arctic lands are home to a growing population of nearly four million people. Nearly one-third of these are people from indigenous groups, who typically live in small communities scattered along the Arctic coast (UNEP, 2008). Much of the coastal indigenous population shares a common cultural heritage and traditional way of life that transcend national boundaries. The lives of indigenous and other northern people are closely linked to natural resources, particularly by their dependence on wildlife harvesting, which forms the basis for the local economies of many small coastal communities. Within Canada, the recent northern Nunavut and Inuvialuit land claim settlements have established co-management boards to ensure equal and meaningful participation by the Inuit in protecting and preserving the Arctic environment and wildlife. The term "co-management" refers to arrangements between aboriginal people, governments, and other parties that specify their respective rights, powers, and obligations with respect to the management and allocations of resources in particular areas of Crown land (Fraser, 1996).

The Arctic Ocean, positioned strategically between two landmasses, offers access to two other world oceans and the potential for lucrative ocean routes between global centres of commerce. It is a semi-enclosed ocean with abundant natural resources that have yet to be fully used. Even with modern technology, extreme environmental conditions have restricted transportation and resource development and limited population growth in the North. But despite the lack of development (and therefore relatively small amounts of locally produced pollution), the concern about impacts of anthropogenic pollution is equal or, in some cases, greater in the North than in countries to the south. This situation is explained by the interplay of the Arctic Ocean with the planet's global energy circulation systems. Deep ocean water produced in the Arctic plays an important role in sustaining the global ocean conveyor belt. Atmospheric and oceanic pathways bring threats from distant contaminant sources to a vulnerable northern environment. In addition, the freshwater input from northflowing rivers, especially the Yenisei, $\mathrm{Ob}$, and Lena, collects and transports industrial wastes from the vast catchment areas extending far to the south.

Research into the complex transportation, distribution, and transformation of chemicals in the Arctic system will be an ongoing requirement. The Arctic system is not static. In particular, climate change continues to have a significant impact on the Arctic environment itself and on the physical, chemical, and biological processes affecting pathways and distribution of pollutants. The emergence of new contaminants and changes to circulation patterns and processes need to be continually monitored and addressed. Environmental and societal changes demand consequential amendments to policies and management decisions. Governments need to introduce programs that respond to the threats and opportunities in the North. The Arctic Ocean is a regional sea. National actions must be compatible with regional demands if the integrity of the whole is to be preserved. Solutions require action and collaboration at all levels of government and need to be founded on reliable and timely knowledge and information. The governments of Arctic countries have already taken some individual and collective actions to address the serious existing and potential environmental issues facing the North. However, many more obstacles remain to be overcome.

\section{GLOBAL THREATS}

The Arctic Ocean forms an essential link in the chain of northern environmental processes, and the land-sea interface is where many of the most serious threats affect society and the environment. The marine environment is a shared resource, and its continued health is a responsibility for all Arctic nations and their peoples. However, the issues facing the Arctic cannot be dealt with solely in a northern context because the Arctic is not isolated from contaminants produced elsewhere in the world.

Ocean, river, and atmospheric pathways transfer a pollutant burden to the North from sources of industrial and 


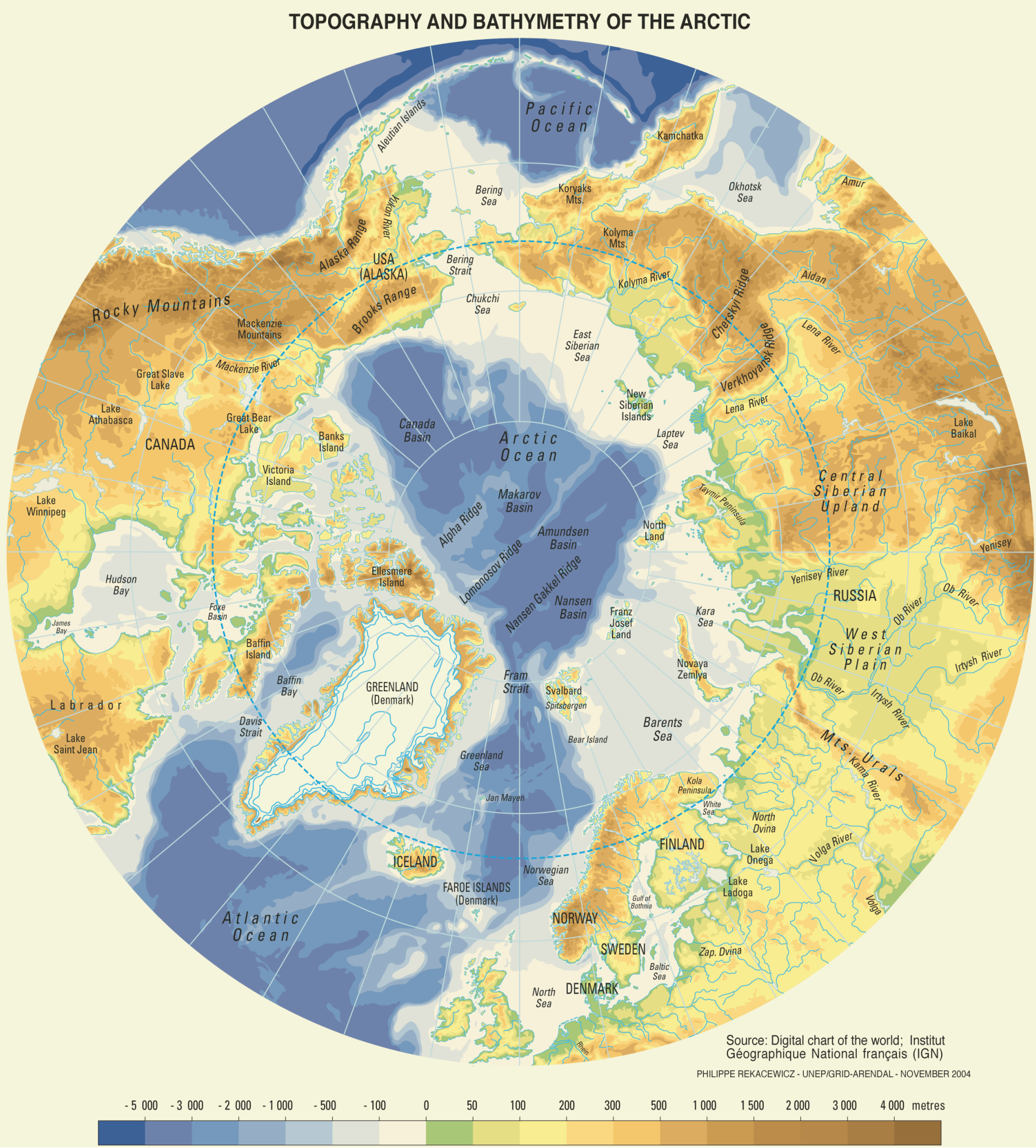

FIG. 1. Arctic seas and coastal areas (map by Philippe Rekacewicz, Le Monde Diplomatique, Paris; reprinted with permission of the author).

agricultural pollution that in most cases lie far to the south. As well, once these contaminants reach the Arctic, the levels of some are increased by physical, chemical, and biological processes to concentrations that pose a significant threat to environmental and human health.
In addition, the Arctic is itself a substantial element of the planet's climatic environment affected by, and contributing to, the natural processes that surround the planet. The most contentious environmental issue today is the measured increase in the atmospheric content of gases that 
limit the outward radiation of the sun's heat. Such increases are predicted to lead to a warming of the climate (the so-called "greenhouse effect"). Carbon dioxide $\left(\mathrm{CO}_{2}\right)$ is the most prevalent of the many greenhouse gases, and the current accelerated rate of increase in atmospheric $\mathrm{CO}_{2}$ is linked to industrial growth and human activities.

The warming trend has far-reaching environmental and social consequences for the Arctic. The Arctic Council initiated an extensive study on the issue, the Arctic Climate Impact Assessment (ACIA). In the overview report, ACIA (2004:2) states:

\footnotetext{
Continuing to add carbon dioxide and other greenhouse gases to the atmosphere is projected to lead to significant and persistent changes in climate... Climatic changes are projected to include shifts in atmospheric and oceanic circulation patterns, an accelerating rate of sea level rise, and wider variations in precipitation. Together, these changes are projected to lead to wide-ranging consequences including significant impacts on coastal communities, animal and plant species, water resources, and human health and well-being.
}

The report found that the impacts of climate change are being felt most intensely in the Arctic, with average temperatures increasing at about twice the rate of the rest of the world over the last few decades. The report also emphasizes that changes in climate occur in the context of many other stresses, and these stresses can combine to amplify impacts on human and ecosystem health and wellbeing. For example, the combined impact of contaminants, ozone depletion, and climatic warming may be greater than the sum of its parts.

However, there is still much to learn about this complex ecosystem. The 2004 ACIA report concentrated on the Arctic, but the broader global focus of the Intergovernmental Panel on Climate Change (IPCC) is also relevant to changes in the northern environment, and its ongoing findings represent the most current opinions and research. The modification of atmospheric and ocean currents by climate change will affect the concentrations and distribution of contaminants in the polar region. Levels of mercury and other heavy metals are expected to increase in the Arctic Ocean, as are the levels of some persistent organic pollutants (POPs). Research is required on the ways in which bioaccumulation and biomagnification will change under a climate-warming scenario, with possible associated future implications for the health of animals and for the levels of contaminants in traditional or country foods.

Global threats will continue to be a concern for the Arctic. World demands are increasing interest in northern resources. Development, coupled with recent warming and ice-cover reduction, are accelerating the rate of change in the North, posing both new opportunities for economic development and threats to traditional cultures and the vulnerable northern environment. In the foreseeable future, the societal demand for resources is unlikely to diminish, and although the present rate of warming in the Arctic may be enhanced by natural climatic cycles, computer models based on greenhouse gas emissions predict a continuing global warming that will be felt most strongly at the poles.

It seems highly likely that the rate of social and environmental changes will continue to be a challenge to the culture and ecology of the region.

\section{SOURCES AND PATHWAYS OF CONTAMINANTS}

\section{General}

The Arctic is dominated by a deep, ice-covered central ocean, with surrounding shallow coastal seas. Contaminant pathways into the Arctic Ocean exist from the North Atlantic via the Norwegian coastal current, from the North Pacific via the Bering Strait, and from major northwardflowing rivers. Atmospheric deposition and direct input from coastal and marine processes and human activities in the North are other significant sources of pollution.

The contaminant load in the Arctic predominantly emanates from sources far outside the region, and the issue can be adequately addressed only through national, pan-Arctic, and global actions. The work of AMAP $(1997,2002)$ has been extremely valuable in determining the levels and sources of Arctic contaminants. Most POPs appearing in the northern environment are a result of industrial and agricultural practices to the south. Although concentrations are generally lower than in more temperate regions, levels of POPs in some species of biota and at some locations are well above acceptable levels and pose a significant health issue. Of particular significance is the danger to indigenous populations through their consumption of traditional foods. A similar situation exists with the presence of heavy metals in the Arctic environment, which can also be linked to distant sources. Of these, high concentrations of mercury, lead, and cadmium present the most serious threat to environmental and human health, although other more exotic metals may be of potential importance.

In general, levels of anthropogenic radionuclides in the Arctic environment are declining, mainly because of the reduction in nuclear weapons testing. For the Arctic marine environment, the major sources of radionuclides have been the releases from European reprocessing plants at Sellafield and Cap de la Hague. Radioactive isotopes are carried north by sea currents to the Norwegian and Barents seas and have resulted in increases in levels of some radionuclides in the European Arctic seas during recent years.

Climate variability and global climate change strongly influence the routes and mechanisms by which contaminants are delivered to the Arctic. These pathways are complex, interactive systems involving a number of factors, such as temperature, precipitation, winds, ocean currents, and snow and ice cover. Pathways within food webs and the effects on biota may also be modified by changes to climate. 
These effects mean that climate-related variability in recent decades may be responsible, at least in part, for some of the trends observed in contaminant levels.

\section{Oceanic Pathways}

The significance of ocean transport for contaminants to, from, and within the Arctic has been increasingly recognized during the past few years. Pollutant transport through the ocean is relatively slow, and contaminants can take years to travel from temperate industrialized coasts to the Arctic. However, since the oceans have a much larger capacity to carry contaminants than the atmosphere, marine pathways are of major importance.

The Arctic Ocean is characterized by three main layers. Arctic deep water, below about $800 \mathrm{~m}$, has a long residence time. At the top is the Arctic surface water (to depths of about $200 \mathrm{~m}$ ), which is the most important layer for contaminant transport within the Arctic Basin. Sandwiched between is the Atlantic Layer. The halocline, a transition zone of increasing salinity, exists between the surface water and the Atlantic Layer and serves as an important barrier to transfer of heat and contaminants from Arctic surface water to the Atlantic water below. Changes in the strength of the halocline can significantly alter pollutant transport. For example, in the 1990s, the halocline in the Eurasian Basin weakened, enabling pollutants to penetrate deeper waters. The most likely reason for the weakening is that wind-pattern changes forced freshwater from the Russian rivers to turn eastward in the Laptev and Kara seas. Freshwater input to the Arctic Ocean is important for the development of stratification in the water column, and the eastward redirection of the Russian river water resulted in a reduction in stratification in the Eurasian Basin and an increased stratification in the Canadian Basin. Specifically, instead of entering the surface Transpolar Drift to exit the Arctic Ocean within about two years, the pollutants could instead access the lower Atlantic layer and thus find their way into the Canadian Basin, where they have a 10 -year residence time. Such a change in pollutant distribution would increase the contaminant load in the Canadian Basin and extend the length of time these pollutants would be available for absorption by the biota or deposit into the sediments there.

The pathways of the surface ocean water follow two basic trajectories: the Transpolar Drift that crosses the Eurasian Basin and exits through Fram Strait, and the circulating Beaufort Gyre on the North American side of the Arctic Ocean. Circulation is influenced by the atmospheric regime. With a high Arctic Oscillation Index, water in the Transpolar Drift moves closer to North America, while the Beaufort Gyre retreats into the Canadian Basin. Ice forming in the shelf seas can be transported into the central part of the Arctic Ocean through these currents. The circulation and subsequent melting of this ice allows contaminants to be redistributed to deep ocean sediments and other shelf seas. The shelf seas, ice edges, and polynyas (areas of open water surrounded by sea ice) are seasonally some of the most biologically productive ecosystems in the world, providing an economic base for several large fishing fleets, as well as a feeding ground for large populations of migratory birds. These areas are at risk of receiving increased contaminant loads, and their high productivity and importance to the food chain will magnify the size and extent of the impact.

\section{Freshwater Pathways}

The catchment area of the Arctic Ocean is extensive, with the drainage basins of Arctic rivers penetrating far to the south. River inputs to the Arctic Ocean represent important pathways for contaminants, as well as affecting the salinity and ocean circulation patterns within the Arctic. Over the past 50 years, increased population and industrial development in the northern catchment areas have adversely affected the quality of the freshwater flowing into the Arctic Ocean, especially from the morepopulated Russian lands.

Several rivers and estuaries in northern Russia suffer from oil contamination. Oil and gas production poses a serious threat to wetlands when wastes are disposed directly into wetland depressions, which act as sinks for contaminated fluids. When these sinks flood, they contaminate local rivers and lakes, which in turn affect coastal waters. Lead, cadmium, and mercury in all Arctic freshwater generally occur at levels lower than $1 \mathrm{ug} / \mathrm{l}$, which is similar to levels in unpolluted areas outside the Arctic. However, in certain regions of Arctic Canada, Russia, Finland, and Alaska, some rivers have lead concentrations that exceed waterquality guidelines for southern latitudes.

DDT is present in Arctic rivers, but concentrations range widely from low levels found in rivers flowing into Hudson Bay to significant concentrations in the Ob River in Russia. There are also high levels of pesticides and other organic chemicals in several Russian rivers, and concentrations of POPs in these rivers draining into the Arctic Ocean are generally higher than those found in urban North America and Western Europe. The rivers of the Kola Peninsula in the Russian Federation suffer a significant decrease in alkalinity during the spring snowmelt, and some streams undergo rapid acidification, although acidification is generally improving over the European Scandinavian countries as a result of decreases in emissions.

Radioactive isotopes have been released into Russian rivers that flow into the Arctic. These releases have come from reprocessing plants and a nuclear weapons production facility, all south of the Russian Arctic. Radioactive isotope levels in Russian rivers have dropped since the 1960s after peaking in the late 1940s and 1950s. Today, the biggest threat is probably from ponds that have been artificially dammed to contain radioactive waste. If these dams were to fail, then significant radioactive contamination could flow down the river system into the Arctic. 


\section{Atmospheric Pathways}

The atmosphere contains relatively low concentrations of contaminants compared with the other media. However, the atmosphere is the fastest transport mechanism for delivering contaminants to the Arctic. Transport times from temperate agricultural and industrialized areas can be weeks or even days.

Time of year and prevailing weather systems determine the fate of contaminants being transported through the atmosphere. In the Arctic winter, particles can stay in the air as long as 20-30 days, creating conditions for longrange transport and accumulation of contaminants in the polar region. In summer, the contaminants usually stay airborne for only two to five days. In addition, during winter and spring, an intense high-pressure system over Siberia pushes the Arctic front far to the south. Large polluted areas of Eurasia are then within the Arctic air mass. The lower part of this air mass, extending $1-2 \mathrm{~km}$ in height, can move contaminants across the pole. This activity is further amplified by the lack of clouds and precipitation during this time; thus, the contaminants travel into the Arctic before they can be deposited in precipitation. Contaminants in the form of minute particles, or aerosols, are relatively easy to track in the atmosphere. Once they land, they usually stay on the ground or get taken up by other pathways. Acids carried as sulphates, non-volatile metals, radionuclides, and gases that transform into particles (such as sulphur dioxide) are some examples. Nonvolatile organic compounds can also be transported as aerosols or particles. The distances over which these types of contaminants travel is determined by the location of their sources in relation to the Arctic air mass, precipitation patterns, and the distance the air mass moves during the atmospheric lifetime of the particles.

The most direct entry route into the polar cap from Europe is associated partly with the extreme sea-land temperature contrast on the western seaboard of Eurasia. Furthermore, because Europe is located at relatively high latitudes, a significant portion of the European emissions can actually be injected directly into the polar cap, especially when pressure systems extend the polar front farther south over Europe.

Some contaminants are transported as gases, especially volatile and semi-volatile organic compounds. Their behaviour is different from that of particle-bound contaminants and aerosols because their journey consists of several repeated steps. The compounds are first picked up by the winds as gases. They can then land on the ground, on ice, or in the oceans by adhering to particles or organic films, as well as by dissolving in water, although this first stop is not necessarily the end of their journey. When summer brings higher temperatures, the compounds can volatilize again, re-enter the atmosphere, and continue their journey as gases. If the contaminants do not break down, as is the case for POPs and mercury, and if the temperature conditions are right, the process can repeat itself a number of times. Eventually, the compounds might break down to less harmful chemicals or be deposited in bottom sediment in oceans and lakes. By means of this repetitive process, compounds can travel great distances and become truly global in distribution. At some point in their journey, winds are likely to carry them into the Arctic, which explains why chemicals that have never been used in the Arctic can still be found in the tissues of people and wildlife in the region. For some compounds, the levels are higher in the Arctic than one would expect, even taking transport into account. As the temperature drops, the compounds condense out of the gas phase onto particles or snowflakes in the air, which eventually land on the ground. These compounds can also condense directly onto the earth's surface. At the low temperatures typical of the Arctic, they are less likely to re-volatilize than in warmer climates. Another explanation is that gases dissolve in water more readily at low Arctic temperatures than in warmer environments.

Levels of mercury in the northern atmosphere suddenly drop in the spring when the sun reappears after the long polar night. Mercury is deposited from the atmosphere onto the snow surface during what is called a Mercury Depletion Event, which may be an important route for this contaminant to enter the food web.

\section{Direct Contributions}

The relatively sparse populations along northern coastlines in the past have meant that sewage and municipal wastewaters were localized and of relatively low concern. With the increase in development, however, populations are growing, particularly in coastal communities. Increases in population and economic activities in coastal areas demand the expansion of supporting infrastructure, which in turn leads to increasing environmental burden and alterations in coastal habitats and waters. Municipal wastewater is the end product of all uses of water within the municipality, including domestic and industrial uses. Wastewater contains suspended solids, biodegradable organics, nutrients, toxic compounds, and pathogens, all of which can affect the environment and human health. Treatment facilities are often nonexistent or inadequate. The Arctic presently has limited ability to deal with any of its human-generated waste products, and the cost of transporting waste to the south is prohibitive.

The remoteness of the North has led to a certain cavalier attitude with respect to the disposal of wastes. In particular in the northern territories of the Russian Federation, the coastal sea was too often used as a cheap disposal option for nuclear and industrial wastes of all types. In North America, during the height of the cold war, the establishment of defence bases was not undertaken with environmental protection as a high priority.

Much has been made of the recent reduction of sea ice and the implications for the North of increased access to ships, both within the Arctic and transiting through it. 
Marine transportation is an essential part of trade and economy, but the opportunities it creates also bring environmental issues that require careful regulation and management. Stack emissions are not negligible, ballast water is an ongoing problem, and incidental discharges through tank and bilge washings and engine wastes are all issues that could be magnified in the polar environment. The Arctic is already attracting cruise ships, whose capacity to transport sightseers in numbers rivaling those of existing local populations presents both an opportunity and a threat that must be given serious attention.

Industrial activities, such as mining and oil and gas exploration and production, will increase. Waste management is, and will continue to be, a serious issue and one that industry must accept as a cost of doing business in the North. The transportation of resources from these activities to southern markets, whether by sea or over land, will need regulations and controls to protect marine and river ecosystems.

\section{WHAT CAN BE DONE?}

Obviously the pathways through which contaminants arrive in the Arctic will continue to exist. However, much can be achieved through the understanding of the processes involved and the monitoring of the contaminants being transported. This understanding and information are essential to identify and reduce pollutant sources. Government action takes place at national, pan-Arctic, and international levels, and at all three levels there is much to be gained from collaboration and cooperation. Arctic countries need to act in concert at the international level to make a compelling case for global action.

Arctic countries must also recognize the wealth of scientific capabilities that exist beyond their regions and use this capacity to its maximum extent. The Arctic is an important part of the planetary environment, and the Arctic's physical, chemical, and biological processes are of global importance. Collaboration in the acquisition of knowledge and data is an effective and efficient way of increasing our mutual understanding of the Arctic environment and the processes involved. Arctic countries should support international initiatives such as the International Polar Year (IPY), an intense and coordinated campaign of research in 2007-08 covering both polar regions and recognizing the strong links these regions have with the rest of the globe (www.ipy.org). For the Arctic, IPY involves programs covering a wide range of research disciplines, including the social sciences, with an interdisciplinary approach and truly international participation.

Regionally, Arctic countries share the Arctic Ocean and the surrounding waters. The quality of the marine and coastal environments cannot be maintained through piecemeal actions. Arctic countries must cooperate regionally to ensure the well-being of the whole marine resource. Regional cooperation extends to national environmental policies and regulations. Ideally, national legislation and rules covering everything from sewage treatment to shipping and resource extraction should be identical across the region. In reality, the complexity of national laws and differences in application and enforcement make such a system impractical. However, minimum standards and compatible legislation are reachable objectives that can be achieved through national and regional actions. The basis for regional accord will depend on the availability and sharing of knowledge and data - and of course on the good will and efforts of the governments concerned. Much has already been accomplished, but more can be achieved.

\section{INTERNATIONAL AND INTERGOVERNMENTAL AGREEMENTS}

\section{Intergovernmental Agreements}

The major threats to the health, productivity, and biodiversity of the marine environment result from human activities. Some $80 \%$ of the pollution load in the oceans originates from land-based activities (UNEP, 1995). This pollution includes municipal, industrial, and agricultural wastes and run-off, as well as atmospheric deposition. These contaminants affect the most productive areas of the marine environment, including estuaries and near-shore coastal waters, and they can be transported to all parts of the globe. To address these issues, the European Commission and 108 governments declared their commitment to protect and preserve the marine environment from the adverse environmental impacts of land-based activities. The Global Programme of Action for the Protection of the Marine Environment from Land-based Activities and the Washington Declaration were adopted in 1995. The United Nations Environment Programme (UNEP) was tasked to lead the coordination effort and to establish a Global Programme of Action (GPA) Coordination Office. The GPA operates through the individual and collective actions by governments under National Programmes of Action (NPAs) and Regional Programmes of Action (RPAs).

The earliest international agreement to tackle the problem of airborne contaminant transport was the United Nations Economic Commission for Europe (UNECE) Convention on Long-Range Transboundary Air Pollution (LRTAP), which came into force in 1983. All of the Arctic countries are parties to the Convention. The Convention has been kept up to date through the addition of eight protocols, the most pertinent to the Arctic being the UNECE Protocol on Persistent Organic Pollutants and the UNECE Protocol on Heavy Metals. Both entered into force in 2003 and have been ratified by most Arctic governments, the exceptions being the United States and the Russian Federation for the POPs Protocol, and Iceland and the Russian Federation for the Heavy Metals Protocol.

The Stockholm Convention, a global convention to protect human health and the environment from POPs, was adopted on 22 May 2001 and came into force on 17 May 
2004. In implementing the convention, governments will take measures to eliminate or reduce the release of specified POPs into the environment. Six of the Arctic governments (Canada, Denmark, Finland, Iceland, Norway, and Sweden) are parties to the Convention. The Russian Federation and the United States have also signed this Convention, although ratification is still awaited.

The Stockholm Convention and the UNECE POPs Protocol permit parties to propose new chemicals to be added to the existing lists of banned and regulated organic compounds as new information becomes available. Both require periodic reviews and regular reports to the respective secretariats. For the UNECE Protocol on Heavy Metals, the addition of other metals to the existing list (cadmium, lead, and mercury) seems unlikely at present.

\section{The Arctic as a Regional Sea}

The eight federal governments of countries surrounding the Arctic Ocean have together formed the Arctic Council in recognition that the issues facing the North exceed the capabilities of any one country and that successful solutions must be built on common actions. The Arctic Council (www.arctic-council.org) has matured significantly since its inauguration in 1996. Of special interest is the participation of permanent participants from indigenous organizations, at present the Aleut International Association, the Inuit Circumpolar Conference, the Russian Association of Indigenous Peoples of the North, and the Saami Council. The Arctic Council also allows observer status. Four nonArctic nations, and a large number of governmental and nongovernmental organizations, participate as observers.

The Arctic Council has achieved a great deal, considering its relatively short existence. It has several working groups and many programs and projects, in addition to the AMAP and the ACIA study already mentioned above, which are relevant to the land-ocean interface and anthropogenic sources of pollution.

The Arctic Council established the Arctic Contaminants Action Program (ACAP) as a working group in 2006, with the goal of reducing emissions of pollutants into the environment (ACAP, 2008). In particular, ACAP has been dealing with serious contamination sources in northern Russia.

Concurrently with the ACIA, the Arctic Council initiated an Arctic Human Development Report (AHDR, 2004), which emphasized the importance of maintaining environmental quality to producing a more stable and sustainable Arctic economy. In terms of human health, the transfer of man-made contaminants in the marine environment and contamination of traditional foods are raised as serious issues. The AHDR notes that an immediate issue is the advice that Arctic residents receive about the risks of consuming contaminated food and therefore the need to monitor closely the success of programs to control the mostly distant sources of problem chemicals. The report also states that "we need to improve our understanding of the roles that modern industrial activities play in the pursuit of sustainable development at the regional level" (AHDR, 2004:239). It encourages national and pan-Arctic environmental programs to ensure that new threats to the marine environment do not materialize.

The Protection of the Arctic Marine Environment (PAME) Working Group has the mandate to address policy and non-emergency pollution prevention and control measures related to the protection of the Arctic marine environment from both land- and sea-based activities. These control measures include coordinated action programs and guidelines complementing existing legal arrangements. PAME played an important advisory role in the preparation and application for Global Environmental Facility funding of the Russian National Plan of Action-Arctic.

One of PAME's responsibilities is to administer the Regional Programme of Action for the Protection of the Arctic Marine Environment from Land-based Activities (RPA), which was developed in response to the GPA. The RPA serves to bridge the gap between the global agreement and the national programs that give it substance, and it supports cooperation, regional compatibility, and the sharing of knowledge. The RPA does not exist in a vacuum, and its articles must remain compatible with related international conventions and protocols to which Arctic governments are parties. A review of the Arctic RPA is included within the PAME work plan for 2006-08. Other relevant PAME activities include the completion of an Arctic Marine Strategic Plan (which was adopted by Arctic Council Ministers in 2004), the development of offshore oil and gas guidelines, and the undertaking of an Arctic Marine Shipping Assessment.

Of particular interest to the present paper are AMAP and its two assessments of the state of the Arctic environment with respect to pollution issues. These assessments, based on the input and contributions from several hundred scientists and experts, are prepared by lead experts working under the guidance of the Assessment Steering Group. AMAP, now a program group of the Arctic Council, states its current objective as "providing reliable and sufficient information on the status of, and threats to, the Arctic environment, and providing scientific advice on actions to be taken in order to support Arctic governments in their efforts to take remedial and preventive actions relating to contaminants" (http://www.amap.no/).

The warming of the Arctic undoubtedly has direct and indirect effects. The extensive study undertaken by the Arctic Council underlines the seriousness of this issue for northern communities. The study found that a significant warming of the Arctic is taking place and that this trend is likely to continue. Changes to precipitation, river flow, ice formation, permafrost, erosion rates, and increased occurrence of extreme events can all influence the amount of pollutants entering the Arctic and how these pollutants are transported.

At the November 2004 Ministerial Meeting in Reykjavik, Iceland, the Arctic Council (2004) issued a policy document that fully endorsed the scientific results of the 
ACIA with respect to climate change and agreed to further organize its work based on those findings. The Council directed relevant technical working groups of the Arctic Council to review the scientific chapters of the ACIA in the context of their ongoing and future work programs, and to report on the progress made. This policy direction would include those programs that related to the quality of the marine environment and the issues of land-based contamination. The Arctic Council has many other important programs relevant to land-based sources of pollution, especially those dealing with the impact of contaminants on northern communities and the many corresponding issues that need to be addressed.

\section{NATIONAL PROGRAMS-THE CANADIAN EXAMPLE}

In Canada, the protection of the marine environment is a shared responsibility. Governments administer a multitude of environmental legislation and regulations, planning measures for land and water use, and other coastal and marine-related legislation. Responsibility for the management of the marine environment and its resources is also shared with the aboriginal peoples in some land-claim settlement areas (Federal/Provincial/Territorial Advisory Committee on the NPA, 2001). Canada is one of four Arctic countries at present with a declared National Programme of Action for the Protection of the Marine Environment from Land-based Activities (NPA). Finland, Iceland, and the Russian Federation are the other three.

Canada's goals for the NPA are to protect human health, reduce the degradation of the marine environment, remediate damaged areas, promote the conservation and sustainable use of marine resources, and maintain the productive capacity and biodiversity of the marine environment. At the national level, high priority is assigned to action on sewage, POPs, shoreline construction or alteration, and wetland and salt marsh alteration. Medium priority is assigned to heavy metals, oils/hydrocarbons, intertidal and sub-tidal alteration, marine waters and coastal watershed alteration, biological alteration, contaminated sediments, and litter. Radionuclides, nutrients, mineral and sediment extraction or alteration are assessed as lowpriority issues for the present.

In the NPA, Canada notes that significant progress has been achieved toward international implementation of the GPA, particularly through the establishment of the Arctic Council and its working groups and the adoption of the Arctic RPA in 1998. The NPA emphasizes the importance of co-operation and capacity building, such as the focus under the RPA to address the regional priority pollution sources found in the Russian Federation through support of the Russian NPA-Arctic.

Canada has had a solid basis upon which to build its policies on Arctic contaminants. In 1991, it established the Northern Contaminants Program (NCP) in response to concerns about human exposure to elevated levels of contaminants in wildlife species that are important in the traditional diets of northern aboriginal peoples. Early studies indicated a wide spectrum of substances found at unexpectedly high levels in the Arctic ecosystem, in particular, POPs, heavy metals, and radionuclides, many of which had no Canadian or Arctic sources.

In Phase I, from 1991 to 1996, NCP research was focused on assessing where contaminants were found in the Arctic and at what levels and on confirming the source region (AES-NCP, 1997). From 1998 to 2003, under Phase II, the NCP shifted towards a greater emphasis on human health research, developing effective community dialogue, increasing community participation, and working towards international agreements to control the release of contaminants (NCP, 2003). Under the current phase of the NCP, the focus is on protecting aboriginal health and safety compromised by contaminants consumed in traditional/ country foods, and on fulfilling Canada's obligations under international agreements.

The extensive research and experience built up during the planning phase and in the execution of the NCP enhanced Canada's ability to work with other Arctic countries and to build a circumpolar case for regional action. Canada was able to contribute significantly to the successful negotiation of the Protocol on POPs under the LRTAP and the Stockholm Conventions. In addition, building on many years of contaminant research in the Arctic environment, the NCP was able to provide information that contributed to the establishment of the LRTAP Protocol on Heavy Metals and to the global assessment of mercury undertaken by UNEP to determine the need for global controls.

The NCP (2003) made several recommendations on contaminants and the physical environment that are pertinent to the present discussion, including recognition of the need to monitor atmospheric levels of new POPs in the physical environment (e.g., brominated flame retardants, chlorinated paraffins, and chlorinated phenols), as well as the POPs that have been of continuing concern because more data are required to determine long-term trends. POPs in seawater should continue to be monitored because ocean currents are now recognized as being more important transport routes than previously thought, and the role of sea ice in moving contaminants from one part of the environment to another needs to be better understood. The NCP (2003) also recommended more modeling and research to increase understanding of the pathways and sources of contaminants as well as the physical, chemical, and biological processes that affect the contaminants once they arrive in the northern environment. The recommended research covered topics as diverse as the importance of microbes in removing contaminants, the nature of the mercury depletion events, and the effect of melting permafrost.

Canada maintains strong contact with the international community, for example, through its membership on the International Arctic Science Committee and the Arctic Ocean Sciences Board. The federal government invested over \$150 million (CAD) on the Canadian program for the 
IPY to gain knowledge of the Arctic and its physical, chemical, and biological processes.

The seventh biennial Coastal Zone Canada Conference was held in Tuktoyaktuk, Northwest Territories, in August 2006 and had as its theme "Arctic Change and Coastal Communities." The 270 participants included aboriginal and non-aboriginal Canadians from across the country, with a significant majority from the Arctic. The Conference recognized that a critical situation exists in the Arctic with an immediate need for care, and called for strengthened stewardship, healthy communities, and adaptation in the face of the many expected changes. The Conference statement (Tuktoyaktuk Declaration; see this issue of Arctic), representing the combined knowledge, experience, and wisdom of a broad collection of interested and concerned Canadians, international experts, and members of the Northern Forum, called on the Canadian government to commit to a second phase of the Oceans Action Plan that incorporates Arctic actions addressing sovereignty, human and ecological dimensions of security, monitoring, climate change adaptation for community well-being, and the management of marine and coastal uses.

\section{CONCLUSIONS}

Land-based contamination of the Arctic is clearly an issue that must be addressed by all levels of government. The focus of action will rest with the national policies of the Arctic governments, from which will stem the cohesiveness of action in support of needed global agreements, pan-Arctic compatibility of environmental policies, and the sharing of knowledge through cooperation in monitoring and research. Of equal importance is the partnership within the country to implement national policies in resource development, management decisions, and environmental practices at federal, provincial, and local levels.

Arctic governments have made a good start at regional cooperation with the establishment of the Arctic Council and its many technical programs. Especially important is the involvement of northern peoples, both through their contribution within national delegations under the authorities provided by co-management agreements and through the participation of permanent representatives. The North is rich in mineral and biological resources, and the further development of the North will create many economic opportunities for Arctic countries. In a sparsely populated and harsh environment, private industries will likely need to shoulder a significant share of the environmental responsibility for sustainable operation of their activities through programs of monitoring and control. Climate change, industrial expansion, and population increases are producing serious environmental impacts with associated influences on northern cultures. The existing cultures and traditional resource use in the North will need to be protected. The governments of Arctic countries will need to give higher priority to northern policies in the future.

\section{ACKNOWLEDGEMENTS}

This paper was prepared by Geoff Holland, who was commissioned by Environment Canada, Fisheries and Oceans Canada, and Indian and Northern Affairs Canada. We are grateful to Dr. Holland for his efforts in writing this paper based on his extensive knowledge and experience. We thank David Rosenberg for editing drafts of the manuscript. We thank Maureen Copley, Erika Kiss, Sarah Kennedy, and Peter Farrington from the NPA Secretariat for their continual coordination and administration of this project.

\section{REFERENCES}

ACAP(ARCTIC CONTAMINANTS ACTION PROGRAM). 2008. http://acap.arctic-council.org/.

ACIA (ARCTIC CLIMATE IMPACT ASSESSMENT). 2004. Impacts of a warming climate. Cambridge: Cambridge University Press. 139 p.

AES-NCP (ARCTIC ENVIRONMENTAL STRATEGY NORTHERN CONTAMINANTS PROGRAM). 1997. Canadian Arctic contaminants assessment report. Ottawa: Department of Indian Affairs and Northern Development. 460 p.

AHDR (ARCTIC HUMAN DEVELOPMENT REPORT). 2004. Edited by Niels Einarsson, Joan Nymand Larsen, Annika Nilsson and Oran R. Young. Akureyri, Iceland: Stefansson Arctic Institute. 242 p.

ALASKA DEPARTMENT OF NATURAL RESOURCES. 2003. Oil and gas in the ANWR? Its Time to Find Out! Anchorage: ADNR, Division of Oil and Gas. 18 p. http://www.dog.dnr. state.ak.us/oil/products/publications/otherreports/ANWR/ ANWR\%20Review_2003-02.pdf.

AMAP (ARCTIC MONITORING AND ASSESSMENT PROGRAMME). 1997. Arctic pollution issues: A state of the Arctic environment report. Oslo, Norway: AMAP. 118 p.

- 2002. Arctic pollution 2002: Persistent organic pollutants, heavy metals, radioactivity, human health, changing pathways. Oslo, Norway: AMAP. 112 p.

ARCTIC COUNCIL. 2004. Arctic climate impact assessment policy document. Issued by the Fourth Arctic Council Ministerial Meeting, Reykjavik, 24 November 2004. http://www.acia.uaf/ edu/PDFs/ACIA_Policy_Document.pdf.

FEDERAL/PROVINCIAL/TERRITORIAL ADVISORY COMMITTEE ON THE NPA. 2001. Implementing Canada's National Programme of Action for the Protection of the Marine Environment from Land-based Activities: National Report to the 2001 Intergovernmental Review Meeting on Implementation of the Global Programme of Action. Ottawa: Environment Canada. 21 p. +43 p. Annex.

FRASER, N. 1996. The Little Red River Cree Nation - Tallcree First Nation co-management agreement: Working towards self-sufficiency. Ottawa: Indian and Northern Affairs Canada. http://ainc-inac.gc.ca/pr/pub/ep/envir3_e.html.

NCP (NORTHERN CONTAMINANTS PROGRAM). 2003. Canadian Arctic contaminants assessment report II. Ottawa: Department of Indian Affairs and Northern Development. 5 vols. http://ainc-inac.gc.ca/ncp/pub/index_e.html. 
UNEP (UNITED NATIONS ENVIRONMENT PROGRAMME). 1995. Global Programme of Action for the Protection of the Marine Environment from Land-based Activities. Washington, D.C.: UNEP. UNEP(OCA)/LBA/IG.2/7. http://www.gpa.unep. org/documents/default.htm.
2008. Canada, Arctic indigenous population. http://maps. grida.no/go/graphic/canada-arctic-indigenous-population. 